\title{
Aspartate transport in Rhizobium meliloti
}

\author{
R. J. Watson, ${ }^{*}$ V. K. Rastogi $\dagger$ and Y.-K. Chan \\ Plant Research Centre, Agriculture Canada, Ottawa, Ontario K1A 0C6, Canada
}

(Received 20 July 1992; revised 29 January 1993; accepted 1 February 1993)

\begin{abstract}
Aspartate transport in Rhizobium meliloti was found to be mediated by at least two transport systems. High rates of aspartate uptake, necessary for growth on aspartate as a carbon source, required the dicarboxylate transport (Dct) system, which also transports succinate, fumarate and malate. The apparent $K_{\mathrm{m}}$ for aspartate transport by this system was about $10 \mathrm{mM}$, compared to $15 \mu \mathrm{M}$ for succinate. This difference in affinity was also apparent in competitive inhibition studies, which showed that succinate effectively inhibits aspartate transport. Although aspartate was not a preferred substrate, it was a very efficient inducer of the Det system. Both the Det system and a second aspartate transport system were capable of supplying aspartate for use as a nitrogen source. The second system had a lower apparent $K_{\mathrm{m}}$ for aspartate transport $(1.5 \mathrm{~mm})$, and was competitively inhibited by glutamate. This aspartate-glutamate system was regulated independently from the Det system, since it functioned in mutants lacking the Det system regulatory genes $\operatorname{dct} B$ and $\operatorname{dct} D$, and its induction did not coactivate the Det system. Uptake kinetics in cultures growing on aspartate as nitrogen source showed rapid substrate exchange between extracellular and internal aspartate. $R$. meliloti was shown to be able to selectively activate the two uptake systems, and also regulated its metabolism as required to utilize aspartate as either carbon or nitrogen source.
\end{abstract}

\section{Introduction}

Rhizobium meliloti is a nitrogen-fixing bacterium which forms a symbiotic association with alfalfa (Verma \& Long, 1983; Haaker, 1988). The bacteria elicit the formation of root nodules, in which they reside and provide an important source of nitrogen for the plant. In turn, the bacteria benefit from the association since they are provided with nutrients. They are induced to grow to high titres within the nodules, in which they differentiate to forms known as bacteroids contained within host plant cells.

The primary energy source for nitrogen fixation is photosynthesis. Organic compounds formed by this process, principally sucrose, are transported to the root and nodules where they are converted to substrates supplied to the bacteroids (McDermott et al., 1989; Streeter, 1991). Studies of $\mathrm{C}_{4}$-dicarboxylate transport $(d c t)$ mutants have provided evidence that dicarboxylates

*Author for correspondence. Tel (613) $9953700 ;$ fax (613) 9927909 .

†Present address: Department of Soil and Crop Sciences, Texas A\&M University, College Station, Texas 77843-2474, USA.

Abbreviation: TCA, tricarboxylic acid. are the major carbon and energy source for $R$. meliloti bacteroids in the nodule (Ronson et al., 1981; Bolton et al., 1986; Engelke et al., 1987; Watson et al., 1988). Mutants unable to transport dicarboxylates into the cell due to mutation of $\operatorname{dct} A$, the structural transport gene, produced nodules which were symbiotically ineffective and contained an underdeveloped symbiotic zone (Watson et al., 1988; Engelke et al., 1989). Bacteroids were found to senesce prematurely within the host cells, such that a senescent zone predominated in the nodule. These studies demonstrated that $\mathrm{C}_{4}$-dicarboxylates are essential for symbiotic nitrogen fixation, and are probably provided to the bacteroids within the host cells.

The Dct system is encoded by three genes, $\operatorname{dct} A, \operatorname{dct} B$ and $d c t D$, located on the exo megaplasmid. The $\operatorname{dct} B$ and $\operatorname{dct} D$ genes encode regulatory proteins which sense dicarboxylates outside the cell and respond by activating the $d c t A$ gene (Ronson et al., 1987b; Jiang et al., 1989; Yarosh et al., 1989; Watson, 1990). In R. meliloti the $\operatorname{dct} A$ gene encodes a highly hydrophobic protein which is thought to reside in the inner membrane and transport dicarboxylates into the cell (Jiang et al., 1989; Engelke et al., 1989; Watson, 1990). Substrates for the Dct system include the TCA cycle intermediates succinate, fumarate and malate, and aspartate. Succinate, fumarate or malate have been considered the most likely of these compounds 
Table 1. Bacterial strains

\begin{tabular}{|c|c|c|}
\hline $\begin{array}{l}\text { R. meliloti } \\
\text { strain }\end{array}$ & Relevant characteristics & Source/reference \\
\hline JJlc10 & Wild-type parent; Det $^{+}$Fix $^{+}$Rif $^{r}$ & Selvaraj et al. (1987) \\
\hline $4 \mathrm{~F} 6$ & $\begin{array}{l}\text { dctA mutant derived from JJlc10 by } \mathrm{Tn} 5 \\
\text { mutagenesis; } \mathrm{Dct}^{-} \mathrm{Fix}^{-} \mathrm{Rif}^{\mathrm{r}} \mathrm{Km}^{\mathrm{r}}\end{array}$ & Watson et al. (1988) \\
\hline R647 & $\begin{array}{l}\text { JJlc10 dct } A:: \operatorname{Tn} 5-35, \operatorname{Tn} 5 \text { introduced by } \\
\text { recombination, carries plasmid pPH } 1 \mathrm{JI} ; \text { Det }^{-} \\
\text {Fix }^{-} \text {Rif }^{r} \mathrm{Km}^{\mathrm{r}} \mathrm{Gm}^{r}\end{array}$ & Watson (1990) \\
\hline R684 & $\begin{array}{l}\mathrm{JJ} 1 \mathrm{cl} 0 \text { dct } A:: \operatorname{Tn} 5-51, \operatorname{Tn} 5 \text { transduced from R646; } \\
\mathrm{Dct}^{-} \mathrm{Fix}^{-} \mathrm{Rif}^{\mathrm{r}} \mathrm{Km}^{\mathrm{r}}\end{array}$ & Watson (1990); this study \\
\hline R716 & $\begin{array}{l}\text { JJ1c10 dctB::Tn5-33, Tn5 transduced from R639; } \\
\text { Dct }^{-} \text {Fix }^{+/-} \text {Rif }^{r} \mathrm{Km}^{\mathrm{r}}\end{array}$ & Watson (1990); this study \\
\hline R717 & $\begin{array}{l}\text { JJlc10 dctD:: Tn5-39, Tn5 transduced from R649; } \\
\mathrm{Dct}^{-} \mathrm{Fix}^{+-} \operatorname{Rif}^{\mathrm{r}} \mathrm{Km}^{\mathrm{r}}\end{array}$ & Watson (1990); this study \\
\hline
\end{tabular}

to serve as carbon and energy substrates for bacteroids, since these have been reported to be taken up most readily by either free-living cells or purified bacteroids (Watson et al., 1988; McRae et al., 1989; Miller et al., 1988). Nevertheless, aspartate remains as a possible substrate supplied to $R$. meliloti within the nodule. Recently, the pathway for aspartate catabolism for use as a carbon and energy source was found to be deamination to oxaloacetate by an aspartate aminotransferase (Rastogi \& Watson, 1991). A mutant of $R$. meliloti lacking this aminotransferase activity was symbiotically defective, implying that this pathway, or its reverse, is in some way necessary for the nitrogen fixation process. It has also been proposed that in bacteroids aspartate is exported during the operation of an aspartate-malate shuttle which would generate reductant, $\mathrm{NADH}$, and thus provide energy for nitrogen fixation (Kahn et al., 1985; Appels \& Haaker, 1991; Kouchi et al., 1991).

To study the metabolic interactions between the host plant and the bacteria, it is first necessary to have a basic understanding of the transport systems involved in the uptake of compounds which may be transferred between them. In this report we describe studies of aspartate transport in $R$. meliloti and define its relationship to the transport of succinate, fumarate and malate. We found that aspartate may be transported by at least two separate systems, depending upon culture conditions, and characterized the two systems.

\section{Methods}

Bacterial strains. $R$. meliloti $\mathbf{J} J \mathbf{l} 10$ is a symbiotically effective strain used as the wild-type parent in these studies. It is a rifampicin-resistant derivative of an alfalfa nodule isolate, IZ450, initially obtained from the Institute Zimotecnico, Sao Paulo, Brazil. JJlc10 also lacks a $200 \mathrm{~kb}$ plasmid band which is present in R. meliloti IZ450 (Adachi et al., 1983). The $d c t$ derivatives of this strain used in this work are shown in Table 1. Transductions were done using phage $\phi \mathrm{M} 12$ as described by Finan et al. (1984).
Medium and culture conditions. Minimal medium used for the growth of $R$. meliloti was $\mathrm{M} 9$, containing $\left(1^{-1}\right): 7 \mathrm{~g} \mathrm{Na}_{2} \mathrm{HPO}_{4}, 3 \mathrm{~g} \mathrm{KH}_{2} \mathrm{PO}_{4}$, $1 \mathrm{~g} \mathrm{NH}_{4} \mathrm{Cl}$ and $1 \mathrm{~g} \mathrm{NaCl}$, with $10 \mathrm{ml}$ each of sterile $0 \cdot 1 \mathrm{M}-\mathrm{MgSO}_{4}$ and $0.01 \mathrm{M}-\mathrm{CaCl}_{2}$ added after autoclaving. The medium was supplemented with $20 \mathrm{~mm}$ carbon source and $5 \mathrm{ml}$ of $1 \%$ yeast extract (Difco) per litre. Yeast extract was found to be required for continued exponential growth of $R$. meliloti in this medium. For experiments with aspartate as nitrogen source, $\mathrm{NH}_{4} \mathrm{Cl}$ was omitted from the $\mathrm{M} 9$ and the medium supplemented with $5 \mathrm{~mm}$-aspartate.

Cultures were grown from single colonies inoculated in a culture tube with $5 \mathrm{ml}$ of medium, grown with shaking at $30^{\circ} \mathrm{C}$ for $24-48 \mathrm{~h}$. This culture was used to inoculate $50 \mathrm{ml}$ of medium in a baffled culture flask which was shaken overnight to obtain an exponentially growing culture. Growth was monitored by measuring optical density at $620 \mathrm{~nm}$ $\left(\mathrm{OD}_{620}\right)$. A second subculture was then made by appropriate dilution in $50 \mathrm{ml}$ of fresh medium to obtain a mid-exponential-phase culture $\left(\mathrm{OD}_{620}=0 \cdot 5-0 \cdot 8\right)$ early the next day.

Transport assays. To induce transport, cells were either cultured directly in medium containing the inducer, or washed and incubated for $1 \mathrm{~h}$ in medium containing inducer. To assay transport the cells were chilled, washed twice in M9, and resuspended in M9. An aliquot of cells was added to a vial shaking at $30^{\circ} \mathrm{C}$ and warmed for $1 \mathrm{~min}$. Labelled substrates were added, and $100 \mu \mathrm{l}$ aliquots sampled at intervals. Uptake was measured using 50 or $100 \mu \mathrm{M}$-succinate containing $1 \mu \mathrm{Ci} \mathrm{ml} l^{-1}$ $\left[2,3-{ }^{14} \mathrm{C}\right]$ succinic acid $\left(37 \mathrm{kBq} \mathrm{m}^{-1}\right)$ (New England Nuclear) or $5 \mathrm{~mm}-$ aspartate containing $2.5 \mu \mathrm{Ci} \mathrm{ml}^{-1} \mathrm{~L}-\left[\mathrm{U}-{ }^{14} \mathrm{C}\right]$ aspartic acid $(92.5 \mathrm{kBq}$ $\mathrm{ml}^{-1}$ ) (New England Nuclear). Samples were filtered through $0.45 \mu \mathrm{m}$ nitrocellulose membrane filters (Schleicher \& Schuell), washed twice with $5 \mathrm{ml} \mathrm{M} 9$, dried, and their radioactivity measured in a scintillation counter. Also, a $20 \mu \mathrm{l}$ aliquot was spotted on a dry filter and counted to measure total radioactivity in the assay culture. Uptake rates were determined from plots of data using six sampling times, or at least two sampling times when a series of substrate concentrations was being assayed. Experiments have been repeated at least twice.

The loss of ${ }^{14} \mathrm{CO}_{2}$ from cultures was determined as follows. A culture of $R$. meliloti grown in M9 medium with mannitol was washed, resuspended in $\mathrm{M} 9$ containing $5 \mathrm{mM}$-aspartate, and induced by incubation for $1 \mathrm{~h}$. Assay of uptake was initiated by addition of $\left[{ }^{14} \mathrm{C}\right]$ succinate to an aliquot of cells to give a final concentration of $50 \mu \mathrm{M}$. Under these conditions, uptake was linear for $5 \mathrm{~min}$, but the substrate was depleted within 5-10 min. Loss of ${ }^{14} \mathrm{CO}_{2}$ was monitored by withdrawing $30 \mu \mathrm{l}$ samples at 1 min intervals and depositing them directly onto membrane filters moistened with $10 \%(\mathrm{w} / \mathrm{v})$ trichloroacetic acid in scintillation vials. The samples were dried in a vacuum oven at $80^{\circ} \mathrm{C}$ for $1 \mathrm{~h}, 10 \mathrm{ml}$ of scintillation fluid was added, and the 

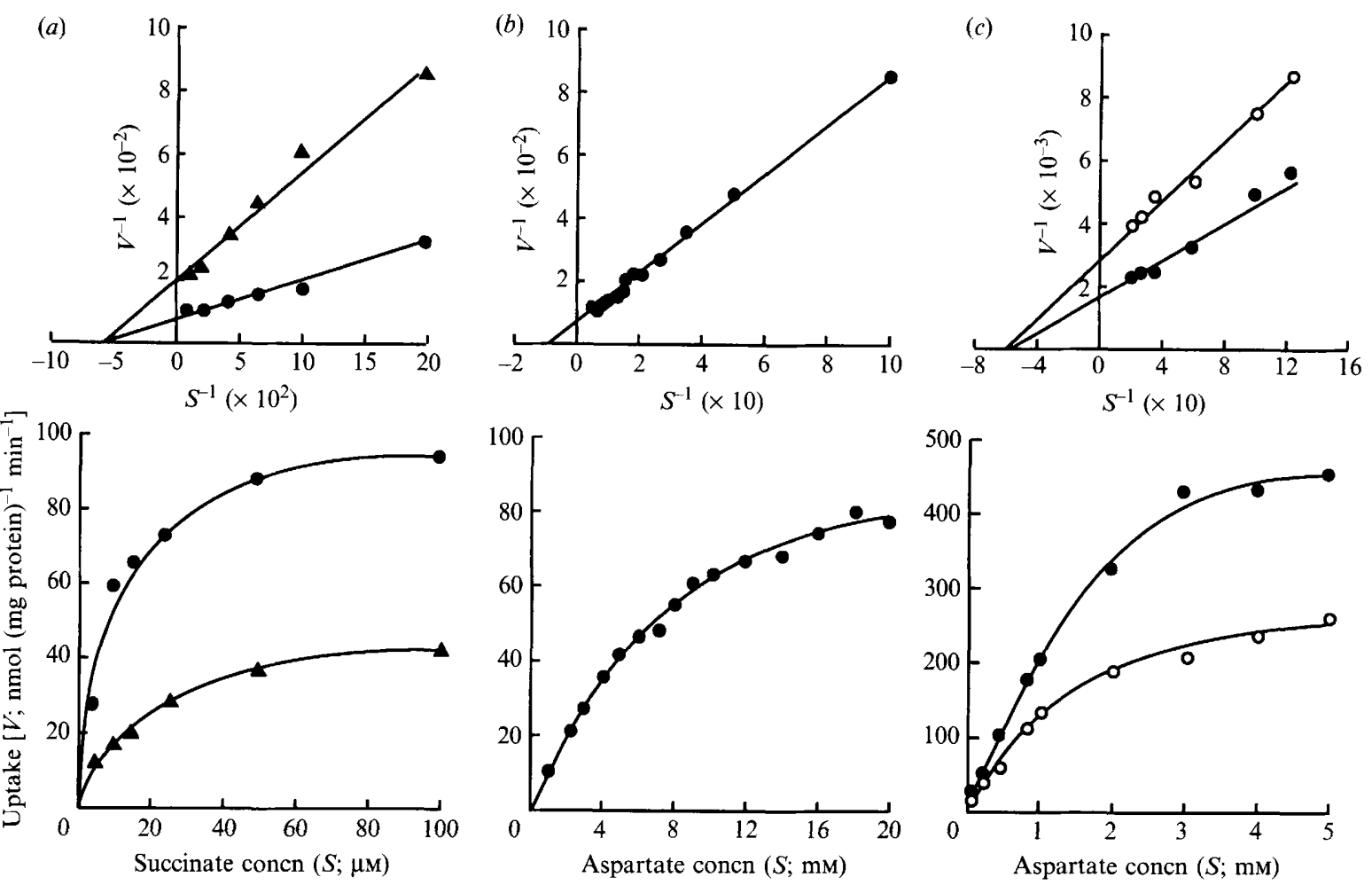

Fig. 1. Determination of apparent $K_{\mathrm{m}}$ values for aspartate and succinate uptake. Lower plots show uptake rates $(V)$ obtained with different substrate concentrations $(S)$. Above each is a plot of $V^{-1}$ versus $S^{-1}$ used to calculate apparent $K_{\mathrm{m}}$ values. (a) $R$. meliloti JJ1c10 succinate uptake by the Dct system. $\boldsymbol{\Theta}$, Aspartate induced; $\boldsymbol{\Delta}$, succinate induced. $(b) \boldsymbol{O}, \boldsymbol{R}$. meliloti JJ1c10 aspartate uptake by the Dct system. (c) Aspartate uptake by the aspartate-glutamate system. O, R. meliloti JJ1c10; $O$, dctB mutant R716.

radioactivity measured. Evolution of ${ }^{14} \mathrm{CO}_{2}$ was calculated as the decrease in radioactivity with time. Samples from the cultures were also assayed for uptake by the membrane filtration technique described above for comparison. Cultures of $R$. meliloti dct mutants unable to transport succinate were used as negative controls.

Protein assay. Protein concentrations were determined using a dye binding assay (Bradford, 1976) purchased as a kit from Bio-Rad. A $1 \mathrm{ml}$ aliquot of cells was centrifuged in a $1.5 \mathrm{ml}$ microfuge tube. The cell pellet was mixed with $20 \mu \mathrm{l} 0 \cdot 1 \%$ sodium dodecyl sulphate (SDS) and the tube placed in a boiling water bath for $2 \mathrm{~min}$. The lysed cells were diluted by addition of $780 \mu \mathrm{l}$ water. Protein standards were treated in parallel by placing $100 \mu \mathrm{l}$ of each in a microfuge tube, adding $20 \mu \mathrm{l}$ $0.1 \%$ SDS, boiling for $2 \mathrm{~min}$, and diluting to $800 \mu \mathrm{l}$ with water. To each tube was added $200 \mu 1$ of the dye reagent mix and the absorbance was determined at $595 \mathrm{~nm}$.

Assay of radiochemical incorporation into trichloroacetic-acid-insoluble compounds. Assay of uptake and incorporation of labelled substrates into trichloroacetic-acid-precipitable compounds in cultures was similar to that described previously (Watson \& Yamazaki, 1973). Aliquots $(100 \mu \mathrm{l})$ of labelled bacterial culture were removed at intervals and deposited on Whatman 3 MM $2.3 \mathrm{~cm}$ filter paper disks which had been numbered with a lead pencil and suspended on pins. Each disk was immediately collected into a beaker of cold $10 \%(\mathrm{w} / \mathrm{v})$ trichloroacetic acid. After standing in ice for at least $30 \mathrm{~min}$, the pins were removed and the disks were washed three times with $5 \%$ trichloroacetic acid on a Buchner funnel under slight vacuum and three times with an ether/ethanol mixture $(1: 1, \mathrm{v} / \mathrm{v})$. The disks were placed into scintillation vials and dried at $80^{\circ} \mathrm{C}$ in a vacuum oven. The radioactivity of the disks was counted in $10 \mathrm{ml}$ scintillation fluid with a liquid scintillation counter.

\section{Results}

Aspartate and succinate transport by the dicarboxylate transport system

In $R$. meliloti, aspartate is taken up by the dicarboxylate transport system when it is provided as the sole source of carbon. A comparison of succinate and aspartate transport at different substrate concentrations is shown in Fig. 1 $(a$ and $b)$. Although succinate at micromolar concentrations was transported readily, aspartate was taken up at a measurable rate only when its concentration was increased above $1 \mathrm{mM}$. The apparent $K_{\mathrm{m}}$ for aspartate transport was $10 \mathrm{mM}$, compared to $15 \mu \mathrm{M}$ for succinate.

The relatively high apparent $K_{\mathrm{m}}$ for aspartate transport was consistent with comparisons of growth rates of $R$. meliloti on aspartate as carbon source when provided at different concentrations. A concentration of $4 \mathrm{~mm}$ aspartate or more was required to achieve the maximum growth rate, a doubling time of about $6 \mathrm{~h}$. At concentrations below $4 \mathrm{~mm}$, growth rate was approxi- 
mately proportional to aspartate concentration. The doubling time in minimal medium with $1.0 \mathrm{~mm}$-aspartate was about $24 \mathrm{~h}$. Strains mutated in the dct $A$ gene showed no growth on aspartate, as described previously (Watson et al., 1988). These data show that the Dct system is the only system in $R$. meliloti capable of aspartate transport for growth on this compound as a carbon source, and that below $4 \mathrm{~mm}$ growth is limited by the high apparent $K_{\mathrm{m}}$ for its transport.

Aspartate transport was rapidly inhibited ( $>90 \%$ ) by either $2 \mathrm{~mm}$-dinitrophenol or $10 \mathrm{~mm}$-sodium azide. The same result was obtained for succinate transport, as reported by others for $R$. leguminosarum and $R$. meliloti (Finan et al., 1981; Engelke et al., 1987). These results indicate that both aspartate and succinate transport by the Dct system are active transport processes.

Inhibition studies were done to compare the relative affinities of the Dct system for aspartate, succinate, fumarate and malate. As shown in Table 2, succinate transport was stoichiometrically inhibited by the presence of fumarate, malate or oxaloacetate. In contrast, aspartate produced little inhibition of succinate transport, even at concentrations 100 -fold higher than that of succinate. Equivalent studies of the effect of dicarboxylates on aspartate transport showed that succinate, fumarate and malate all drastically inhibit its transport, even when added at one-tenth the concentration of aspartate. These inhibition results are in agreement with the differences in apparent $K_{\mathrm{m}}$ values for aspartate compared to succinate.

Under our standard assay conditions, uptake by the Dct system is linear for $5 \mathrm{~min}$, as expected if this represents the initial rates of transport by the system. However, Salminen \& Streeter (1991) showed that uptake measurements using ${ }^{14} \mathrm{C}$-labelled substrates may underestimate the true rate due to evolution of ${ }^{14} \mathrm{CO}_{2}$ during metabolism. To provide an estimate of the magnitude of this effect in our experiments, we measured ${ }^{14} \mathrm{CO}_{2}$ production as the decrease of total radioactivity from $R$. meliloti cultures taking up $\left[{ }^{14} \mathrm{C}\right]$ succinate, as described in Methods. These experiments showed that the radioactivity retained in cells collected on membrane filters represented only $70 \%$ of the total uptake, taking into account the measured loss of ${ }^{14} \mathrm{CO}_{2}$. The evolution of ${ }^{14} \mathrm{CO}_{2}$ was detected within $1 \mathrm{~min}$, and paralleled the uptake measured using filtration (data not shown).

Table 3 shows comparisons of the relative degrees of induction of the Det system by different compounds. Only $\mathrm{C}_{4}$-dicarboxylates induced the system to a high rate of uptake. There was a low but significant uptake by cells grown with other substrates or by cells starved for a carbon source. Glucose-grown cells characteristically showed the lowest rate of transport, but this was still significantly higher than uptake rates obtained using $d c t$
Table 2. Inhibition of succinate and aspartate uptake in $R$. meliloti by various carbon substrates

\begin{tabular}{|c|c|c|c|c|c|c|}
\hline \multirow{3}{*}{$\begin{array}{c}\text { Carbon } \\
\text { substrate }\end{array}$} & \multirow{3}{*}{$\begin{array}{c}\text { Substrate } \\
\text { concn ... }\end{array}$} & \multicolumn{5}{|c|}{ Inhibition $(\%)$} \\
\hline & & \multicolumn{3}{|c|}{ Succinate* } & \multicolumn{2}{|c|}{ Aspartate $\dagger$} \\
\hline & & $50 \mu \mathrm{M}$ & $500 \mu \mathrm{M}$ & $5000 \mu \mathrm{M}$ & $500 \mu \mathrm{M}$ & $5000 \mu \mathrm{M}$ \\
\hline Glucose & & ND & 14 & 8 & 14 & 23 \\
\hline Succinate & & ND & ND & ND & 89 & 92 \\
\hline Fumarate & & 57 & 90 & 99 & 88 & 91 \\
\hline Malate & & 50 & 88 & 98 & 87 & 90 \\
\hline Aspartate & & 2 & 16 & 12 & ND & ND \\
\hline Oxaloacetate & & 34 & 85 & ND & ND & ND \\
\hline Glutamate & & ND & 3 & 6 & 5 & 13 \\
\hline
\end{tabular}

ND, Not determined.

* Cultures were grown in M9 medium with 20 mm-succinate as carbon source. Assays were performed using $50 \mu \mathrm{M}-\left[{ }^{14} \mathrm{C}\right]$ succinate with $50 \mu \mathrm{M}, 500 \mu \mathrm{M}$ or $5000 \mu \mathrm{M}$ carbon substrate tested as inhibitor. The uptake rate in the absence of additional carbon substrate averaged $42 \mathrm{nmol} \mathrm{m^{-1 }}$ (mg protein) $)^{-1}$.

†Cultures were grown in M9 medium with $20 \mathrm{~mm}$-aspartate as carbon source. Assays were performed using $5000 \mu \mathrm{M}-\left[{ }^{14} \mathrm{C}\right]$ aspartate with $500 \mu \mathrm{M}$ or $5000 \mu \mathrm{M}$ carbon substrate tested as inhibitor. The uptake rate in the absence of inhibitors averaged $40 \mathrm{nmol} \mathrm{min}{ }^{-1}(\mathrm{mg}$ protein) $)^{-1}$

Table 3. Induction of succinate uptake by different carbon sources in $R$. meliloti

Cultures were induced in M9 medium plus the carbon source indicated $(20 \mathrm{mM})$. The cultures were washed and resuspended in M9 medium without carbon source. Assays were initiated by adding $50 \mu \mathrm{M}-\left[{ }^{14} \mathrm{C}\right]$ succinate and measuring uptake for $5 \mathrm{~min}$, or $5 \mathrm{~mm}-\left[{ }^{14} \mathrm{C}\right]$ aspartate and measuring uptake for $15 \mathrm{~min}$. ND, Not determined.

\begin{tabular}{|c|c|c|}
\hline \multirow[b]{2}{*}{ Carbon source } & \multicolumn{2}{|c|}{$\begin{array}{l}\text { Uptake }[\text { nmol min } \\
\left.\text { protein })^{-1}\right]\end{array}$} \\
\hline & Succinate & Aspartate \\
\hline Mannitol & 7 & ND \\
\hline Glucose & 4 & 9 \\
\hline Succinate & 45 & 18 \\
\hline Fumarate & 33 & 23 \\
\hline Malate & 68 & 34 \\
\hline Aspartate & 92 & 40 \\
\hline Oxaloacetate & 19 & ND \\
\hline Glutamate & 10 & ND \\
\hline 2-Oxoglutarate & 8 & ND \\
\hline None & 14 & ND \\
\hline
\end{tabular}

mutants $\left.\left[<1 \mathrm{nmol} \min ^{-1} \text { (mg protein }\right)^{-1}\right]$. Despite its high apparent $K_{\mathrm{m}}$ for transport, aspartate was a very efficient inducer, consistently causing initial succinate uptake rates 1.5-2 times higher than succinate-induced cells. Even at $1 \mathrm{~mm}$, a concentration which does not support significant growth of $R$. meliloti, aspartate induced the Dct system to a higher degree than $20 \mathrm{mM}$ succinate. 


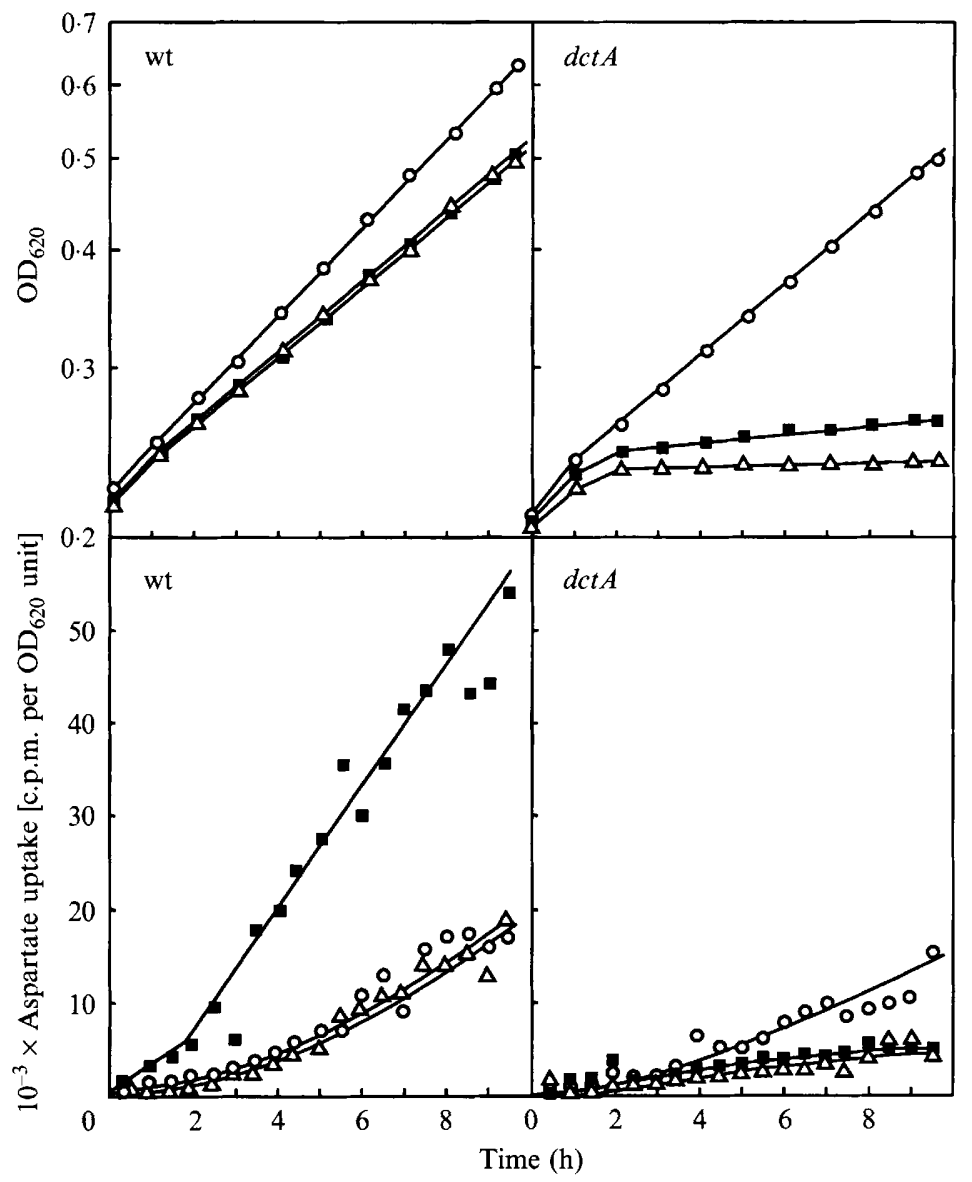

Fig. 2. Incorporation of $\left[{ }^{14} \mathrm{C}\right]$ aspartate by cultures of $R$. meliloti JJ1c10 and $d c t A$ mutant $4 \mathrm{~F} 6$ with different carbon sources and aspartate as sole nitrogen source. Exponentially growing cultures in M9 medium with $20 \mathrm{~mm}$-mannitol were harvested, washed and resuspended in $\mathrm{M} 9$ medium without $\mathrm{NH}_{4} \mathrm{Cl}$. Portions of the cultures were then supplemented with: $\square, 5$ mM-aspartate; $\triangle$ $20 \mathrm{~mm}$-succinate plus $5 \mathrm{~mm}$-aspartate; and $\bigcirc$, $20 \mathrm{~mm}$-mannitol plus $5 \mathrm{~mm}$-aspartate. Growth was monitored by reading culture optical density (top); $\left[{ }^{14} \mathrm{C}\right]$ aspartate was added to portions of each culture to monitor aspartate uptake (bottom). wt, Wild-type $R$. meliloti; $\operatorname{dct} A, \operatorname{dct} A$ mutant $4 \mathrm{~F} 6$.

\section{Aspartate transport as a nitrogen source}

$R$. meliloti derivatives mutated in $\operatorname{dct} A, \operatorname{dct} B, \operatorname{dct} D$ or $n \operatorname{tr} A$ have been found to grow as well as the wild-type on minimal media in which aspartate is provided as the sole source of nitrogen, and containing a separate carbon source such as glucose or mannitol (Watson, 1990). These results imply the presence of a second aspartate transport system. To examine this second system and its relationship to the Dct system, we have studied the uptake of aspartate for use as a nitrogen source in $\mathrm{Dct}^{+}$ and $\mathrm{Dct}^{-} R$. meliloti.

Fig. 2 shows the growth and $\left[{ }^{14} \mathrm{C}\right]$ aspartate uptake of cultures of wild-type $R$. meliloti JJ1c10 and its $\operatorname{dct} A$ derivative $4 \mathrm{~F} 6$ during $10 \mathrm{~h}$ growth in three minimal media with aspartate as sole nitrogen source. The highest uptake occurred when aspartate was supplied to the wild-type strain, JJ1c10, as both carbon and nitrogen sources. Aspartate is transported exclusively by the Dct system under these growth conditions. When succinate was also provided, the rate of $\left[{ }^{14} \mathrm{C}\right]$ aspartate incorporation in the JJ1c10 culture was less, about $30 \%$ of the rate attained by the wild-type culture growing with aspartate alone, demonstrating that succinate is trans- ported for use as a carbon source in preference to aspartate. In this case a separate system for the transport of aspartate for use as a nitrogen source must be active, since succinate is a potent competitive inhibitor of aspartate transport by the Dct system. When mannitol was present as a possible carbon source, aspartate was incorporated at about the same rate as in the succinate plus aspartate culture. Apparently, mannitol was also preferred over aspartate as a carbon source, but aspartate uptake continued at a lower rate to supply nitrogen.

As expected, little growth or uptake of aspartate occurred in the 4F6 (dctA) culture when either aspartate or succinate were the only carbon sources. However, the culture grew well when mannitol was present as a carbon source and aspartate as sole nitrogen source, and $\left[{ }^{14} \mathrm{C}\right]$ aspartate was incorporated at about the same rate as in the wild-type.

These results demonstrated that $R$. meliloti is able to regulate the rate of aspartate utilization in response to the availability of carbon and energy substrates and its requirement for nitrogen. This regulation involves the activation of an aspartate transport system other than Dct as required to provide the cells with aspartate as a nitrogen source. Here, we will refer to this second system 


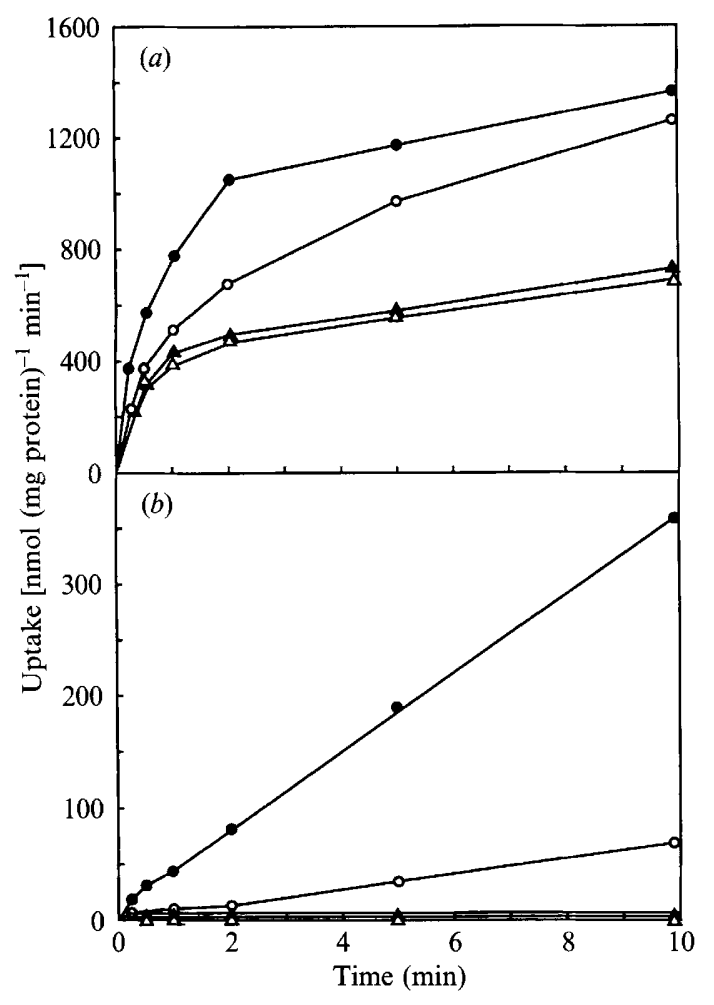

Fig. 3. Aspartate and succinate uptake by cultures grown with aspartate as nitrogen source. Exponential cultures were grown in M9 medium without $\mathrm{NH}_{4} \mathrm{Cl}$ with $20 \mathrm{~mm}$-mannitol and $5 \mathrm{~mm}$-aspartate. Aspartate uptake $(a)$ was measured after addition of $\left[{ }^{14} \mathrm{C}\right]$ aspartate; succinate uptake ability $(b)$ was measured after addition of $\left[{ }^{14} \mathrm{C}\right]$ succinate. $O$, Wild-type $R$. meliloti; $\mathrm{O}, \operatorname{dct} A$ mutant $4 \mathrm{~F} 6 ; \boldsymbol{\Delta}, \operatorname{dct} B$ mutant R716; $\triangle$, dctD mutant R717.

as the aspartate-glutamate system, since, as described below, it also transports glutamate.

\section{The aspartate-glutamate transport system}

Fig. 3 shows assays of aspartate transport in cultures growing with mannitol as carbon source and aspartate as nitrogen source. Several dct mutants were used to discriminate between aspartate transport by the Dct system and that of the aspartate-glutamate system. In these experiments samples of each culture were also assayed for $\left[{ }^{14} \mathrm{C}\right]$ succinate uptake as an indication of Dct activity.

Uptake of $\left[{ }^{14} \mathrm{C}\right]$ aspartate as a nitrogen source did not show the linear kinetics characteristic of its uptake for use as a carbon source. The initial rates of uptake were over 10-fold greater than those characteristic of aspartate or succinate uptake by the Dct system for use as a carbon source. The rates then decreased to a constant, lower value. Since these cultures were in steady-state growth, and were not manipulated other than to add a trace of radioactive aspartate to the $5 \mathrm{~mm}$-aspartate already present, the rapid, initial uptake of label must be due to equilibration of aspartate inside the cells with that outside by an exchange reaction. Therefore, net aspartate uptake by these cultures must be represented by the plateau rates rather than initial rates. This phenomenon also indicates the presence of internal aspartate pools which were largest in the wild-type cells.

Activity of the aspartate-glutamate system alone was demonstrated by $\left[{ }^{14} \mathrm{C}\right]$ aspartate uptake by the cultures of R716 (dctB) and R717 (dctD). These cultures were unable to take up succinate, nor was the aspartate uptake by these mutants inhibited by succinate. Instead, it was found that aspartate uptake was inhibited by glutamate, with aspartate and glutamate serving as equivalent substrates for the aspartate-glutamate system (Table 4).

Wild-type $R$. meliloti showed activity of both the Dct and aspartate-glutamate systems. The presence of an active Dct system was indicated by the ability of the culture to take up succinate (Fig. $3 b$ ). This demonstrated that Dct contributes to the uptake of aspartate for use as a nitrogen source, and is induced by aspartate under these conditions. The aspartate-glutamate system was also operating, since addition of succinate as an inhibitor during $\left[{ }^{14} \mathrm{C}\right]$ aspartate uptake resulted in only a $66 \%$ decrease in the initial aspartate uptake rate (Table 4). The uptake kinetics of the wild-type strain in the presence of succinate corresponded with those shown for aspartate-glutamate system transport by R716 and R717 in Fig. 3. Addition of glutamate resulted in a $40 \%$ decrease in $\left[{ }^{14} \mathrm{C}\right]$ aspartate uptake, an amount consistent with competitive inhibition of its aspartate-glutamate system component.

Unexpectedly, the $\operatorname{dct} A$ mutant $4 \mathrm{~F} 6$ exhibited aspartate uptake kinetics intermediate between those of the wild-type and the $d c t B$ and $d c t D$ mutants. It was also found to take up succinate at about $20 \%$ the rate of the wild-type and this uptake was inhibited by malate (Table 4). This mutant carries a $\operatorname{Tn} 5$ insertion near the $5^{\prime}$ end of the $\operatorname{dct} A$ gene, but these results showed that it still exhibited residual activity of the Dct system. We have found that this phenotype is not characteristic of all $d c t A$ mutants; analysis of two other independent $\operatorname{dct} A:: \operatorname{Tn} 5$ mutants, R647 and R684, showed that they exhibit as little succinate uptake as R716 (dctB) and R717 (dctD). Therefore, the Tn5 insertion in $4 \mathrm{~F} 6$ is unusual in that a low level of transport function was still detectable. This level of transport appears sufficient to maintain an aspartate pool in the cell as large as that in the wild-type, but the initial $\left[{ }^{14} \mathrm{C}\right]$ aspartate equilibration by exchange was slower.

Determination of the $K_{\mathrm{m}}$ for aspartate transport by the aspartate-glutamate system using wild-type $R$. meliloti and $\mathrm{R} 716\left(\right.$ dct B) is shown in Fig. 1(c). The $K_{\mathrm{m}}$ was found to be $1.5 \mathrm{~mm}$. At low aspartate concentrations 


\section{Table 4. Inhibition of succinate and aspartate uptake in R. meliloti grown with aspartate as nitrogen source}

Cultures were grown with $20 \mathrm{~mm}$-mannitol and $5 \mathrm{~mm}$-aspartate. Succinate uptake was measured by addition of $100 \mu \mathrm{M}-\left[{ }^{14} \mathrm{C}\right]$ succinate with or without $20 \mathrm{mM}$-malate as inhibitor. Uptake was sampled for $10 \mathrm{~min}$ as in the experiments shown in Fig. 2. Aspartate uptake was measured by addition of $\left[{ }^{14} \mathrm{C}\right]$ aspartate with or without $20 \mathrm{~mm}$-succinate or glutamate as inhibitors. Uptake was sampled for $10 \mathrm{~min}$ as in the experiments shown in Fig. 2. Abbreviations: Asp, aspartate; Suc, succinate; Glut, glutamate; Mal, malate; ND, not determined.

\begin{tabular}{|c|c|c|c|c|c|c|}
\hline \multirow[b]{2}{*}{ Strain } & \multirow[b]{2}{*}{ Genotype } & \multicolumn{2}{|c|}{$\begin{array}{l}\text { Succinate uptake } \\
{\left[\mathrm{nmol} \mathrm{min}^{-1}(\mathrm{mg}\right.} \\
\left.\text { protein })^{-1}\right] \\
\text { (\% inhibition in } \\
\text { parentheses) }\end{array}$} & \multicolumn{3}{|c|}{ 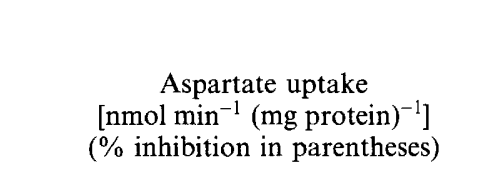 } \\
\hline & & Suc & Suc + Mal & Asp & Asp + Suc & Asp + Glut \\
\hline $\mathrm{JJ} 1 \mathrm{cl0}$ & wt & 88 & $5 \cdot 3(88)$ & 256 & $88(66)$ & $153(40)$ \\
\hline $4 \mathrm{~F} 6$ & dct $A$ & 15 & 1.0 & 260 & $154(41)$ & ND - \\
\hline R716 & $d c t B$ & 0.5 & ND - & 115 & $110(4)$ & $30(74)$ \\
\hline R717 & $d c t D$ & $0 \cdot 2$ & $\mathrm{ND} \quad-$ & 107 & $100(6)$ & $27(75)$ \\
\hline
\end{tabular}

$(<100 \mu \mathrm{M})$ there remained a low rate of uptake which was about equal in both strains, and which did not fit a straight-line double-reciprocal plot (data not shown). This indicates that there might be a third aspartate transport system which operates under these growth conditions, but it appears to be a high-affinity system which contributes little to aspartate uptake at concentrations above $1 \mathrm{~mm}$ compared to the other two systems.

\section{Discussion}

In this study, two aspartate transport systems have been characterized in $R$. meliloti. The Dct system is well known from other studies, but its role in aspartate transport has not previously been examined. An aspartate-glutamate transport system, active during growth on aspartate as a nitrogen source, has also been identified.

Metabolites identified as substrates for the Dct system are aspartate and the TCA cycle intermediates succinate, fumarate, malate and oxaloacetate. A large difference in the affinity of the Dct system was found for aspartate compared to succinate, fumarate and malate. The approximately 600 -fold higher affinity makes succinate or the other TCA cycle intermediates highly inhibitory to aspartate transport, and cells exposed to a mixture will preferentially take up the other dicarboxylates before aspartate. Although the Dct system is known in other bacteria, a marked difference in substrate affinities has not been noted (Kay et al., 1987).

The Dct system was found to be inducible by its substrates. Despite the low affinity of the Det system for aspartate as a substrate, it was a very effective inducer.
The difference is consistent with a model in which transport and induction are mediated by separate components of the Dct system. In the current model for dct gene regulation, DctB protein is thought to be the sensor which detects dicarboxylates outside the cell membrane, and, through the DctD protein, activates the structural gene, dctA (Ronson et al., 1987 b). A refinement of this model suggests that DctB protein does not sense dicarboxylates directly, but instead is proximal to DctA protein in the membrane, and senses dicarboxylates by monitoring activity of this protein (Ronson et al., 1987b; Yarosh et al., 1989). Our observations of induction of the system by aspartate do not favour this latter possibility, since we observed high levels of induction by aspartate concentrations which were severely limiting its transport as a substrate.

The Dct system is also induced when aspartate is present as a nitrogen source, and functions actively in the transport of aspartate for this purpose. The involvement of the Dct system in nitrogen utilization is consistent with the fact that the $d c t A$ gene is transcribed from a $\sigma^{54}$ type RNA polymerase promoter (Ronson et al., $1987 b$; Jiang et al., 1989; Watson, 1990). This characteristic is usually, but not universally, associated with nitrogen regulation (ntr) genes and genes involved in nitrogen metabolism (Magasanik, 1982; Ronson et al., 1987a).

The aspartate-glutamate system transports aspartate for use as a nitrogen source and recognizes aspartate and glutamate as substrates. It appears to be regulated, possibly partly in response to a nitrogen requirement, but is not directly induced by aspartate. It has a relatively low apparent $K_{\mathrm{m}}$ for aspartate, about $1.5 \mathrm{~mm}$ compared to $10 \mathrm{~mm}$ for the Dct system. The difference in apparent 
$K_{\mathrm{m}}$ values for the two systems is such that their relative contributions to aspartate transport vary with extracellular aspartate concentration. At concentrations below about $5 \mathrm{~mm}$ the proportion of aspartate transported by the Dct system decreased in favour of transport by the aspartate-glutamate system. In addition to functioning as a higher-affinity system for aspartate transport for use as a nitrogen source, this second system is also necessary for aspartate transport when a dicarboxylate preferred by the Dct system, such as succinate, is present as a carbon source.

$R$. meliloti is able to regulate the rate of aspartate utilization in response to availability of carbon and energy substrates and its requirement for nitrogen. This regulation involves the activation of the aspartateglutamate transport system in addition to the Dct system. However, the utilization of aspartate as a nitrogen source appears to be primarily regulated at the level of its metabolism. For example, when $5 \mathrm{~mm}$ aspartate must serve as both carbon and nitrogen source, the Dct system alone is able to supply about $40 \mathrm{nmol}$ aspartate $\min ^{-1}$ (mg protein) ${ }^{-1}$. At the same aspartate concentration, but with mannitol also present, the cells choose mannitol as main source of carbon instead of aspartate. The rate of aspartate uptake is then only about $10 \mathrm{nmol} \mathrm{min}^{-1}$ (mg protein $)^{-1}$, even though the Dct system is fully induced, as measured by its capacity for succinate uptake, and the aspartate-glutamate system is also operating. The lower rate of aspartate metabolism in the presence of these two active uptake systems apparently results in a marked increase in size of internal aspartate pools, as evidenced by the initial rapid exchange of exogenous and endogenous aspartate in uptake assays.

Streeter \& Salminen (1990) have found that in Bradyrhizobium japonicum bacteroids a periplasmic aspartate aminotransferase activity, released from cells by dilute detergent, is present which can mediate transfer of nitrogen from aspartate to 2-oxoglutarate. They suggested that in our $d c t A$ mutant, $R$. meliloti $4 \mathrm{~F} 6$, the ability to utilize aspartate as a nitrogen source could be accounted for by a similar transamination and subsequent uptake of the glutamate into the cytoplasm. In support of this idea, they subsequently demonstrated the presence of aspartate aminotransferase activity which could be released from this mutant by mild detergent treatment. In the case of the studies done here, it is clear that this mechanism of nitrogen transfer is not the major route for aspartate nitrogen uptake, since aspartate utilization was accompanied by proportional incorporation of the ${ }^{14} \mathrm{C}$-radiolabel.

Interestingly, the $d c t B$ and $d c t D$ genes are not required for $d c t A$ function in the nodule, since mutants in these genes are nearly as effective symbiotically as wild-type $R$. meliloti (Watson et al., 1988; Engelke et al., 1989; Yarosh et al., 1989). This suggests that an activator other than DctD protein turns on $d c t A$ in the nodule. Since both the Dct and aspartate-glutamate systems are activated when aspartate is present as a nitrogen source, our experiments tested the possibility that an aspartateglutamate system activator may also turn on the $\operatorname{dct} A$ gene. However, since no Dct function was detected in cultures of $d c t B$ or $d c t D$ mutants growing with aspartate as nitrogen source, cross-talk between the two systems cannot account for $\operatorname{dct} A$ gene activation in the nodule.

The Dct system is required for symbiotic nitrogen fixation at the stage of the symbiosis in which the bacteria have proliferated within the host cells. It is unlikely that the Dct system requirement solely involves transport of aspartate for use as a nitrogen source, since the aspartate-glutamate system is also able to provide this function. As the aspartate-glutamate system was found not to operate in free-living cells when aspartate is both carbon and nitrogen source, it remains possible that aspartate serves both functions in the nodule.

We are grateful to Roselyn Heys for technical assistance. This publication is PRC no. 1453.

\section{References}

AdACHI, T., HoOper, I. \& IYER, V. N. (1983). Moderately large plasmids of Rhizobium meliloti. Canadian Journal of Microbiology 29, 1601-1606.

Appels, A. A. \& HaAKER, H. (1991). Glutamate oxaloacetate transaminase in pea root nodules. Plant Physiology 95, 740-747.

Bolton, E., Higgisson, B., Harrington, A. \& O'Gara, F. (1986). Dicarboxylic acid transport in Rhizobium meliloti: isolation of mutants and cloning of dicarboxylic acid transport genes. Archives of Microbiology 144, 142-146.

BRADFORD, M. M. (1976). A rapid and sensitive method for the quantitation of microgram quantities of protein utilizing the principle of protein-dye binding. Analytical Biochemistry 72, 248-254.

ENGelke, T., Jagadish, M. N. \& PuHLeR, A. (1987). Biochemical and genetical analysis of Rhizobium meliloti mutants defective in $\mathrm{C}_{4^{-}}$ dicarboxylate transport. Journal of General Microbiology 133, 3019-3029.

Engelke, T., Jording, D., KaPp, D. \& Puhler, A. (1989). Identification and sequence analysis of the Rhizobium meliloti dctA gene encoding the $\mathrm{C}_{4}$-dicarboxylate carrier. Journal of Bacteriology 171, $5551-5560$.

Finan, T. M., Wood, J. M. \& Jordan, D. C. (1981). Succinate transport in Rhizobium leguminosarum. Journal of Bacteriology 148 , 193-202.

Finan, T. M., Hartwieg, E., Lemieux, K., Bergman, K., Walker, G. C. \& SigneR, E. R. (1984). General transduction in Rhizobium meliloti. Journal of Bacteriology 159, 120-124.

HAAKER, H. (1988). Biochemistry and physiology of nitrogen fixation. BioEssays 9, 112-117.

Jiang, J., Gu, B., Albright, L. M. \& Nixon, B. T. (1989). Conservation between coding and regulatory elements of Rhizobium meliloti and Rhizobium leguminosarum dct genes. Journal of Bacteriology 171, 5244-5253.

KahN, M. L., Kraus, J. \& Somerville, J. E. (1985). A model of nutrient exchange in the Rhizobium-legume symbiosis. In Nitrogen Fixation Research Progress, pp. 193-199. Edited by H. Evans, P. Bottomley \& W. E. Newton. New York: M. J. Nijhoff.

Kay, W. W., Sweet, G. D., Widenhorn, K. \& SOMERs, J. M. (1987). 
Transport of organic acids in prokaryotes. In Ion Transport in Prokaryotes, pp. 269-302. Edited by B. P. Rosen \& S. Silver. San Diego: Academic Press.

KouChI, H., FuKa, K. \& Kihara, A. (1991). Metabolism of glutamate and aspartate in bacteroids isolated from soybean root nodules. Journal of General Microbiology 137, 2901-2910.

MAGASANIK. B. (1982). Genetic control of nitrogen assimilation in bacteria. Annual Review of Genetics 16, 135-168.

McDermott, T. R., Griffith, S. M., Vance, C. P. \& Graham, P. H. (1989). Carbon metabolism in Bradyrhizobium japonicum bacteroids. FEMS Microbiology Reviews 63, 327-340.

McRae, D. G., Miller, R. W., Berndt, W. B. \& Joy, K. (1989). Transport of $\mathrm{C}_{4}$-dicarboxylates and amino acids by Rhizobium meliloti bacteroids. Molecular Plant-Microbe Interactions 2, 273-278.

Miller, R. W., McRae, D. G., Al-Jobore, A. \& Berndt, W. B. (1988). Respiration supported nitrogenase activity of isolated Rhizobium meliloti bacteroids. Journal of Cellular Biochemistry 38, $35-49$.

RAStOGI, V. K. \& Watson, R. J. (1991). Aspartate aminotransferase activity is required for aspartate catabolism and symbiotic nitrogen fixation in Rhizobium meliloti. Journal of Bacteriology 173, 2879-2887.

Ronson, C. W., Lyttleton, P. \& Robertson, J. G. (1981). C $4^{-}$ dicarboxylate transport mutants of Rhizobium trifolii form ineffective nodules on Trifolium repens. Proceedings of the National Academy of Sciences of the United States of America 78, 4284-4288.

Ronson, C. W., Nixon, B. T., Albright, L. M. \& Ausubel, F. M. (1987a). Rhizobium meliloti ntrA (rpoN) gene is required for diverse metabolic functions. Journal of Bacteriology 169, 2424-2431.

Ronson, C. W., Astwood, P. M., Nixon, B. T. \& Ausubel, F. M. $(1987 \mathrm{~b})$. Deduced products of $\mathrm{C}_{4}$-dicarboxylate transport regulatory genes of Rhizobium leguminosarum are homologous to nitrogen regulatory gene products. Nucleic Acids Research 15, 7921-7934.

Salminen, S. O. \& Streeter, J. G. (1991). Improved analysis of metabolite uptake by Bradyrhizobium japonicum bacteroids. Canadian Journal of Microbiology 37, 238-243.

Selvaraj, G., Hooper, I., Shantharam, S., Iyer, V. N., Barran, L., WHEATCROFT, R. \& WATSON, R. J. (1987). Derivation and molecular characterization of symbiotically deficient mutants of Rhizobium meliloti. Canadian Journal of Microbiology 33, 739-747.

STREETER, J. G. (1991). Transport and metabolism of carbon and nitrogen in legume nodules. Advances in Botanical Research 18, 129-187.

Streeter, J. G. \& Salminen, S. O. (1990). Periplasmic metabolism of glutamate and aspartate by intact Bradyrhizobium japonicum bacteroids. Biochimica et Biophysica Acta 1035, 257-265.

VERMA, D. P. S. \& LoNG, S. (1983). The molecular biology of Rhizobium-legume symbiosis. International Review of Cytology (Suppl.) 14, 211-245.

WATSON, R. J. (1990). Analysis of the $\mathrm{C}_{4}$-dicarboxylate transport genes of Rhizobium meliloti: nucleotide sequence and deduced products of $\operatorname{dct} A$, dctB, and $\operatorname{dctD}$. Molecular Plant-Microbe Interactions $\mathbf{3}$, $174-181$.

WATSON, R. \& YAmAZAKI, H. (1973). Alkali hydrolysis of RNA of Escherichia coli deposited on filter paper disks. Analytical Biochemistry 51, 312-314.

Watson, R. J., Chan, Y.-K., Wheatcroft, R., YanG, A.-F. \& HaN, S. (1988). Rhizobium meliloti genes required for $\mathrm{C}_{4}$-dicarboxylate transport and symbiotic nitrogen fixation are located on a megaplasmid. Journal of Bacteriology 170, 927-934.

Yarosh, O. K., Charles, T. C. \& Finan, T. M. (1989). Analysis of C $4^{-}$ dicarboxylate transport genes in Rhizobium meliloti. Molecular Microbiology 3, 813-823. 